\title{
IN VITRO EFFECTS OF SELENIUM ON HUMAN GLIOBLASTOMA MULTIFORME CELL LINES: A PRELIMINARY STUDY
}

\author{
Duygu Harmanci ${ }^{1,3}$, Zubeyde Erbayraktar ${ }^{2}$, Oya Sayin $^{3}$ and Gul Akdogan Guner ${ }^{4}$ \\ ${ }^{1}$ Dokuz Eylul University Graduate School of Health Sciences, Department of Molecular Medicine, \\ ${ }^{2}$ Dokuz Eylul University School of Medicine, Department of Medical Biochemistry, \\ ${ }^{3}$ Dokuz Eylul University Research Laboratory R-LAB; \\ ${ }^{4}$ İzmir University of Economics, School of Medicine, Izmir, Turkey
}

\begin{abstract}
SUMMARY - Glioblastoma multiforme (GBM) is caused by the central nervous system-derived glial cells, and represents the most common (50\%-60\%) form of primary brain tumors. The aim of this study was to investigate the in vitro effects of selenium on human GBM cells. In the present study, GMS-10 and DBTRG-05MG human GBM cell lines were used as a model to examine selenium entering the cell, cell proliferation, cytotoxicity, DNA fragmentation and Ki-67 protein expression in selenomethionine treated and non-treated groups. Seleno-L-methionine (SeMet) as the organic source of selenium exerted effects on cell proliferation and cytotoxicity, as assessed with WST-1 and lactate dehydrogenase (LDH) tests, respectively. Apoptosis was assessed by DNA fragmentation with an enzyme-linked immunosorbent assay. Ki-67 protein expression was determined by Western blotting, while selenium measurements were performed in the supernatants and lysates by using Graphite Furnace Atomic Absorption Spectrometry. This is the first study to examine the effects of SeMet on cell proliferation and death in GMS-10 and DBTRG-05MG cells. Both GBM cell lines responded to SeMet in a dose- and time-dependent manner. WST-1 test showed that low-dose SeMet treatment $(50$ and $100 \mu \mathrm{M})$ increased cell proliferation. Analysis of intracellular SeMet levels by using AAS showed results consistent with viability and cytotoxicity tests. SeMet treatment for $72 \mathrm{~h}$ caused increased DNA fragmentation in both cell lines. In conclusion, our results suggest that SeMet induces cell death at high doses, while increasing cell proliferation at low doses. In the view of the data obtained in this investigation, further studies focusing on the possibility of using SeMet against different types of GBM and in combination with prospect synergic compounds are considered to be worthwhile.
\end{abstract}

Key words: Glioblastoma - therapy; Anticarcinogenic agents; Humans; Selenium; Selenomethionine; Cell proliferation - drug effects; Cell death - drug effects; Cytotoxicity; Ki-67 antigen

\section{Introduction}

Selenium is an essential trace element and an extraordinary element ${ }^{1,2}$. Its own codon enables its incorporation into proteins as selenocysteine ${ }^{3}$. Selenium

Correspondence to: Duygu Harmanci, $M S c$, Dokuz Eylul University Graduate School of Health Sciences, Department of Molecular Medicine, Izmir, Turkey

E-mail: duyguharmanci@gmail.com

February 23, 2015, accepted June 13, 2016 functions in antioxidant mechanisms, immune systems, detoxification mechanisms, inflammation, male fertility, and also exerts anti-cancer effects ${ }^{4}$. Several studies have shown that certain selenium compounds, such as selenite and seleno-L-methionine, have roles as chemopreventive agents in different cancers, including prostate, melanoma, lung, esophageal and gastriccardia cancers ${ }^{5-7}$.

Glioblastoma multiforme (GBM) is the most aggressive brain cancer due to its capacity of rapid inva- 
sion and its strong resistance to therapy ${ }^{8}$. Median survival is 10 to 12 months 9 . Some patients can live up to 14 months $^{10,11}$. Several reports have shown that treatment with antioxidants is beneficial in preventing tumor growth. Recently, temozolomide, bevacizumab, and other alkylating agents are used in the treatment of glioblastoma, but drug resistance is the most important problem ${ }^{12,13}$. To overcome this therapeutic challenge, new approaches involving a combination of anti-cancer drug and antioxidant treatment have been developed ${ }^{14}$.

Previous studies have investigated, both in vitro and in vivo, the preventive and therapeutic effects of selenium on different cancers, including prostate ${ }^{5,15}$, lung $^{16}$, colon ${ }^{17}$, breast $^{7}$, melanoma ${ }^{18}$, and various brain tumors $^{19-22}$. Inorganic forms of selenium, including sodium selenite and sodium selenate, have been used in these studies.

To our knowledge, seleno-L-methionine (SeMet), the organic form of selenium, has not been tested in any study. We hypothesized that SeMet would be effective in controlling cell proliferation and apoptotic cell death. Here, we investigated, on two different human GBM cell lines, the effects of SeMet on proliferation, cytotoxicity, and $\mathrm{Ki}-67$ protein expression. In addition, correlation with the amount of selenium entering the cell (following treatment with different doses of SeMet) was also evaluated.

\section{Materials and methods}

\section{Test chemicals}

Seleno-L-methionine (MW $196.11 \mathrm{~g} / \mathrm{mol}$, CAS Number 3211-76-5; Sigma, USA) was dissolved in distilled water. Then, the solution was filtered and diluted as required. All dilutions were carried out using the medium. All treatments were carried out at final concentrations of 50,100, 500 and $1000 \mu \mathrm{M}$.

\section{Cell culture}

Adherent human GBM cells, GMS-10 and DBTRG-05MG, were obtained from the German Collection of Microorganisms and Cell Cultures (DSMZ). GMS-10 cells were cultured in Dulbecco's Modified Eagle's Medium (DMEM, D6046; Sigma; USA), while DBTRG-05MG cells were cultured in RPMI 1640 (Hyclone, Thermo Scientific; USA) sup- plemented with $10 \%$ fetal calf serum (Biological Industries, Israel), 1\% L-glutamine (G7513; Sigma; USA), and 1\% penicillin-streptomycin (P4333; Sigma; USA) at $37{ }^{\circ} \mathrm{C}$ in $95 \%$ air and $5 \% \mathrm{CO}_{2}$ incubator ${ }^{23,24}$. Cells were trypsinized at a split ratio of $1: 2$ or $1: 3$.

\section{SeMet treatment}

Both cell lines were treated with different concentrations of SeMet $(50-1000 \mu \mathrm{M})$ for 24, 48 and $72 \mathrm{~h}$. Afterwards, cell survival was assessed qualitatively by light microscopy.

\section{Cell viability assay}

The inhibition of cell growth was determined by [2-(4-iodophenyl)-3-(4-nitrophenyl)-5-(2,4-disulfophenyl)-2H-tetrazolium] kit (WST-1 05015944 001, Roche). All GBM cells were seeded on 96-well plates $\left(1 \times 10^{4}\right.$ cells/well) and treated with 50, 100, 500 and $1000 \mu \mathrm{M}$ SeMet for 24, 48 and $72 \mathrm{~h}$. Then, $10 \mu \mathrm{L}$ of WST-1 stock solution was added to each well. Cells were incubated at $37^{\circ} \mathrm{C}$ for $0.5-4 \mathrm{~h}$. After incubation, cell viability was assayed by measuring the absorbance at $440 \mathrm{~nm}$ on a microplate reader (Bio-Tek Instruments, Inc., USA). The results were expressed as mean optical density (OD) of experimental groups $(\mathrm{n}=5)$ vs. control (non-treated cells). The mean OD of the control group was set to represent $100 \%$ cell viability ${ }^{25}$.

\section{Cell death assay}

Cell death was analyzed by using lactate dehydrogenase (LDH) assay (LDH 11644793 001, Roche). Quantifying the amount of $\mathrm{LDH}$ in the medium from dead cells and dividing the result by the total amount of LDH in the medium and cell lysate in the sample calculated the cell cytotoxicity percentage. Cell cytotoxicity results were expressed as the percentage of $\mathrm{LDH}$ released. All GBM cells were seeded on 96-well plates $\left(1 \times 10^{4}\right.$ cells/well) and treated with 50, 100, 500 and $1000 \mu \mathrm{M}$ SeMet for 24, 48 and $72 \mathrm{~h}$. Then, a $10-\mu \mathrm{L}$ lysis solution was added to the wells to achieve maximal release in maximal group cells. Cells were incubated at $37{ }^{\circ} \mathrm{C}$ for $2 \mathrm{~h}$ for lysis. After incubation, LDH working solution was added to each well (supernatants without cell) and LDH released from the medium was detected by measuring absorbance at 490 $\mathrm{nm}$ using a microplate reader (Bio-Tek Instruments, Inc., USA) ${ }^{26}$. 


\section{Cell death ELISA}

Apoptosis was assessed by DNA fragmentation with an enzyme-linked immunosorbent assay (Cell Death ELISA Plus Kit 11774425001, Roche). Briefly, $1 \times 10^{4}$ cells/well were seeded on 96-well plates and treated with 50,100, 500, and $1000 \mu \mathrm{M}$ SeMet for 24, 48 and $72 \mathrm{~h}$. The plate was centrifuged at $600 \mathrm{~g}$ at $4{ }^{\circ} \mathrm{C}$ for 10 minutes and then the supernatants were removed. The cell pellet containing apoptotic bodies was lysed with $0.2 \mathrm{~mL}$ of a lysis buffer (cell death ELISA Plus, Roche) and incubated for 30 minutes at room temperature. Cell lysate solutions $(20 \mu \mathrm{L})$ were placed in duplicate into the wells of the streptavidin-coated microplate, to which $80 \mu \mathrm{L}$ of the immunoreagent containing a mixture of anti-histone-biotin and antiDNA-POD was added. The plate was covered with an adhesive cover foil and incubated for $2 \mathrm{~h}$ at $25^{\circ} \mathrm{C}$ in a shaking incubator at $300 \mathrm{rpm}$. During the incubation period, the anti-histone antibody binds to the histone component of the nucleosomes and simultaneously captures the immunocomplex to the streptavidincoated microplate via its biotinylation. At the same time, the anti-DNA-POD antibody reacts with the DNA component of the nucleosomes. The unbound antibodies were washed with the incubation buffer. The amount of nucleosomes retained by the POD in the immunocomplex, corresponding to the extent of apoptosis was quantitatively determined photometrically with ABTS (2,2'-azinobis-3-ethyl-benzothiazoline-6-sulfonic acid) as substrate, using a microplate reader at a wavelength of $405 \mathrm{~nm}$ and reference wavelength of $490 \mathrm{~nm}$. The enrichment of mono- and oligonucleosomes in the cytoplasm of the apoptotic cells is due to the fact that DNA degradation occurs several hours before the plasma membrane breakdown. Quantifying the average OD from dead cells and dividing the result by that of average control cells yielded the enrichment factor.

\section{Selenium measurement}

Cell lysates and supernatants, which were obtained from the cell lines after incubation, were collected for selenium measurements, which were done by using Graphite Furnace Atomic Absorption Spectrometry (GFAAS). After incubation, cell media were collected and transferred to sterile falcons and the cells were scraped with a cell scraper. The 1000-ppm selenium standard (Titrisol Merck) solution was diluted to 1 ppm in $0.1 \mathrm{M} \mathrm{HCl}$ and then prepared to buffer stock concentrations in the range of $25-800 \mu \mathrm{g} / \mathrm{L}$. All these buffer stock solutions were diluted to working concentrations in the range of $5-200 \mu \mathrm{g} / \mathrm{L}$ with the matrix modifier which was composed of $190 \mathrm{mg}$ palladium nitrate and $60 \mathrm{mg}$ magnesium nitrate, $200 \mu \mathrm{L}$ triton $\mathrm{X}-100$ dissolved in $100 \mathrm{~mL} 0.1 \mathrm{M} \mathrm{HCl}$. Before analysis, cell lysates were diluted (1:100) with the matrix modifier. The matrix modifier was used as blank. All standards and samples were then placed in the auto sampler vial for GFAAS analysis. The sample injection volume was $20 \mu \mathrm{L}$. Selenium was detected at $196 \mathrm{~nm}^{27-29}$.

\section{Western blot}

Following SeMet incubation, the cell lines were lysed in lysis buffer (50 mM Tris- $\mathrm{HCl}(\mathrm{pH} 7.4), 150$ $\mathrm{mM} \mathrm{NaCl}, 20 \mathrm{mM} \mathrm{MgCl}, 1 \%$ Nonidet P-40, 0.1\% sodium dodecyl sulfate (SDS), and $1 \mathrm{mM} \mathrm{PMSF}$, aprotinin $(1 \mu \mathrm{g} / \mathrm{mL})$ and leupeptin $(1 \mu \mathrm{g} / \mathrm{mL}))$. After the cells had been lysed, the protein concentrations were measured using a BCA protein assay kit (Pierce BCA Protein Assay Kit 23225, Thermo Scientific). Equal amounts of total cellular protein samples (15 $\mu \mathrm{g})$ were separated on a $6 \%$ SDS-polyacrylamide gel at $100 \mathrm{~V}$ and transferred onto a PVDF membrane for $2 \mathrm{~h}$ at $200 \mathrm{~mA}$ (Atto). The membranes were incubated with 5\% non-fat dry milk and 3\% BSA, specific primary antibodies at 1:250 and 1:500 directed to either Ki-67 (Santa Cruz, Cat No. sc-7844) and calnexin (Santa Cruz, Cat No. sc-6465) overnight at $4{ }^{\circ} \mathrm{C}$, followed by incubation with appropriate HRP conjugated secondary antibodies (donkey anti-goat IgGHorseradish Peroxidase Conjugated Affinity Purified Antibody, Santa Cruz, Cat No. sc-2020) at 1:1000 dilution in PBS for $1 \mathrm{~h}$ at room temperature and subsequent chemiluminescent detection using standard quality $\mathrm{x}$-ray films ${ }^{30}$.

\section{Statistical analysis}

All data were expressed as mean \pm SD and corresponded to the results of at least three independent experiments. The average of five wells was taken for each parameter. The cells treated with the medium served as control (100\% viable) and the remaining samples were expressed as viability percentage decrease 
or increase as compared with the control. Kolmogorov-Smirnov test was used to assess whether the variables fitted normal distribution and showed a nonnormal distribution. One-way ANOVA was used to analyze differences among these non-normally distributed groups. Pearson's correlation test was used to determine correlation among experimental parameters. $P$ values $<0.05$ were considered as statistically significant. SPSS v.19.0 (Chicago, IL, USA) was used for statistical analysis.

\section{Results}

\section{SeMet treatment suppresses GBM cell proliferation in a dose- and time-dependent manner}

Two human GBM cell lines were treated with increasing concentrations of SeMet for 24, 48 and $72 \mathrm{~h}$. Then, cell viability was assessed by the WST-1 assay. As shown in Figure 1A and B, SeMet stimulated proliferation of cell lines in a dose-dependent manner. For the GMS-10 cell line, low doses $(50 \mu \mathrm{M}$ and $100 \mu \mathrm{M})$ were found to induce proliferation at $24 \mathrm{~h}$ (Fig. 1A). We did not find significant difference between the SeMet treated two cell lines for $24 \mathrm{~h}$, but a significant difference $(\mathrm{p}<0.05)$ was found for $48 \mathrm{~h}$ and $72 \mathrm{~h}$ (Fig. 1). After $72-\mathrm{h}$ SeMet treatment, the $\mathrm{IC}_{50}$ values were $500 \pm 200 \mu \mathrm{M}$ for GMS-10 and $500 \pm 100 \mu \mathrm{M}$ for DBTRG-05MG.

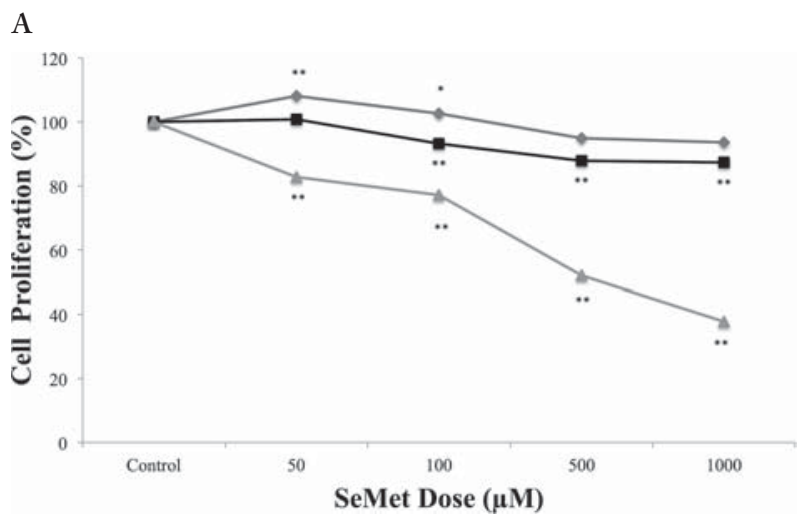

\section{SeMet treatment induces apoptosis in GBM cells}

The LDH assay showed that high dose SeMet treatment $(500 \mu \mathrm{M}$ and $1000 \mu \mathrm{M})$ induced cell death

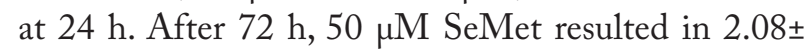
$0.45 \%$ increase, $100 \mu \mathrm{M}$ in $13.26 \pm 0.76 \%$ increase, 500 $\mu \mathrm{M}$ in $35.52 \pm 1.37 \%$ increase and $1000 \mu \mathrm{M}$ in $50.10 \pm$ $2.29 \%$ increase in cell death for the DBTRG-05MG cell line compared with control. For the GMS-10 cell line, $50 \mu \mathrm{M}$ SeMet resulted in no death, whereas 100 $\mu \mathrm{M}$ resulted in $3.99 \pm 0.65 \%, 500 \mu \mathrm{M}$ in $10.0 \pm 0.89 \%$ and $1000 \mu \mathrm{M}$ in $20.96 \pm 1.90 \%$ increase in cell death compared with control. Furthermore, we found negative correlation between the results of the $\mathrm{LDH}$ assay and WST-1 assay. The results of the LDH assay correlated negatively with the results of the WST-1 assay. Pearson's correlation test results and the related $\mathrm{r}$ and $\mathrm{p}$ values are indicated in Table 1.

\section{DNA fragmentation: apoptotic effects of SeMet}

DNA fragmentation analysis showed that SeMet induced apoptosis in both GBM cell lines after 72-h incubation. To quantify and further support the finding that SeMet treatment causes cell death in GBM cells, we performed cell death detection by ELISA. Compared with controls, treatment of GMS-10 cells with SeMet at $500 \mu \mathrm{M}$ and $1000 \mu \mathrm{M}$ concentrations resulted in 2.94- and 4.03-fold increase in the induction of apoptosis, respectively.

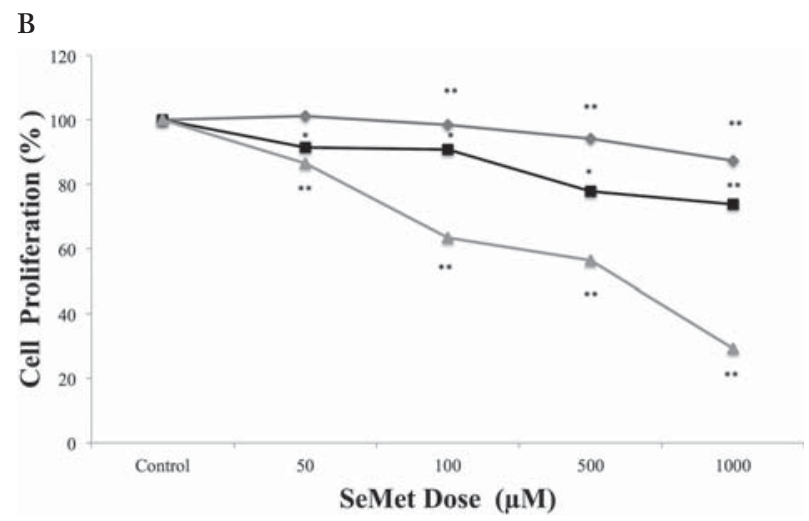

GMS-10 and DBTRG-05MG cells were treated with different doses of SeMet and cell proliferation was assayed at different time points: (A) WST-1 assay of cell proliferation of GMS-10 cells treated with four different doses of SeMet using 24 h, 48 h, and 72 h incubation times; (B) WST-1 assay of cell proliferation of DBTRG-05MG cells treated with four different doses of SeMet. The results were expressed as the mean optical density (OD) of experimental groups $(n=5)$ vs. control (non-treated cells). The mean OD of the control group was set to represent $100 \%$ cell viability. Data represent the mean of three independent experiments compared with control group $(* * \mathrm{p}<0.01$, *p<0.05).

Fig. 1. Seleno-L-methionine (SeMet) suppresses glioblastoma multiforme (GBM) cell proliferation in a doseand time-dependent manner. 
A (a)

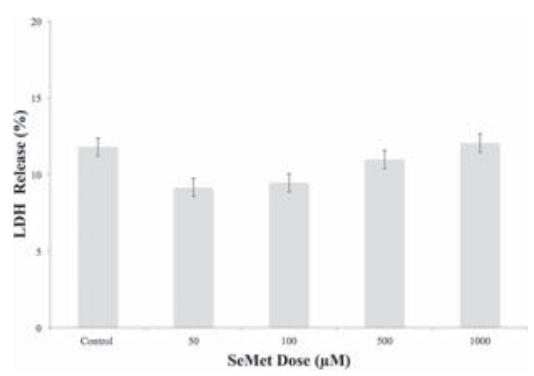

B (a)

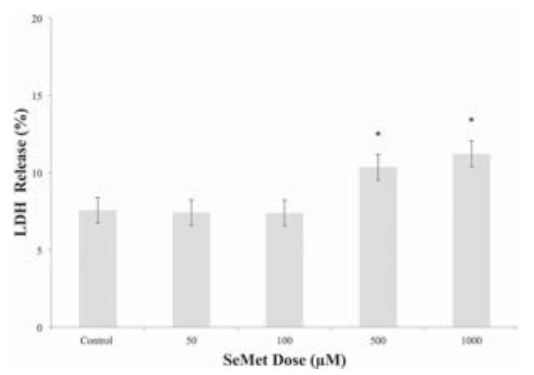

C (a)

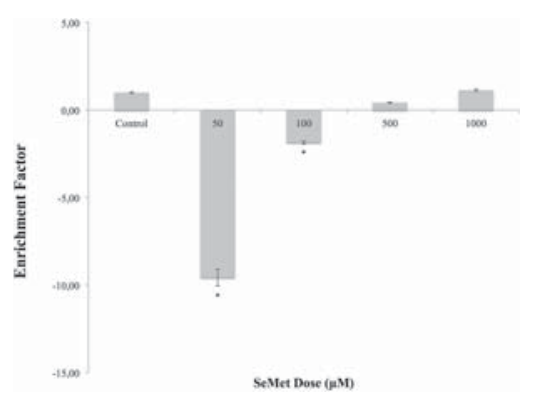

$\mathrm{D}$ (a)

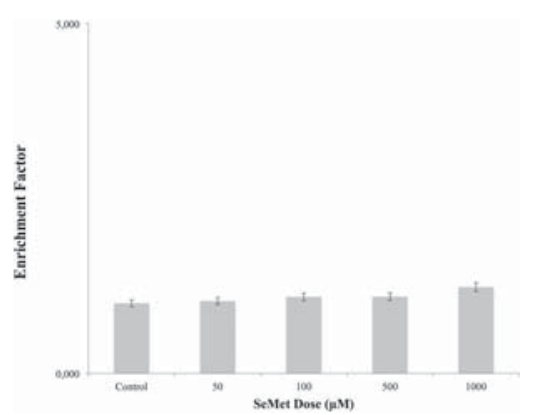

A (b)

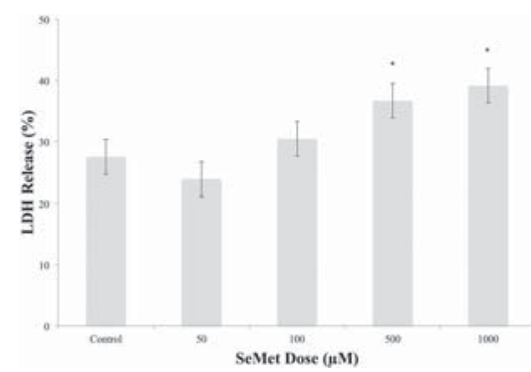

B (b)

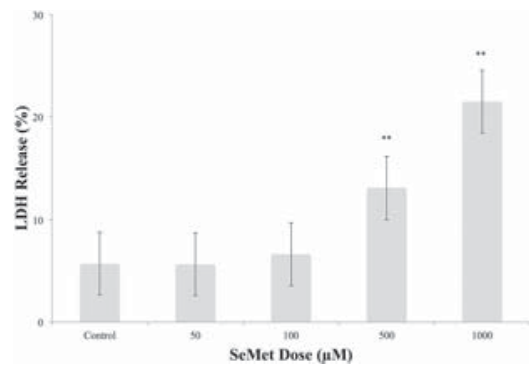

C (b)

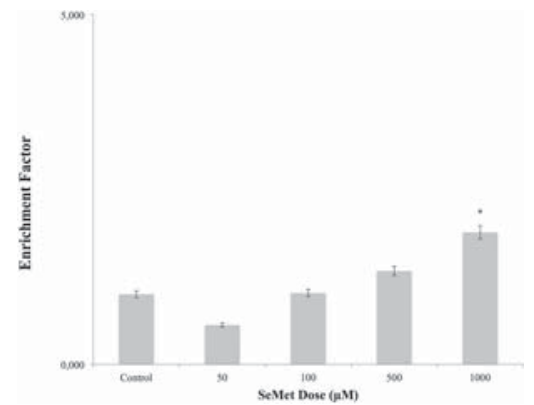

$\mathrm{D}$ (b)

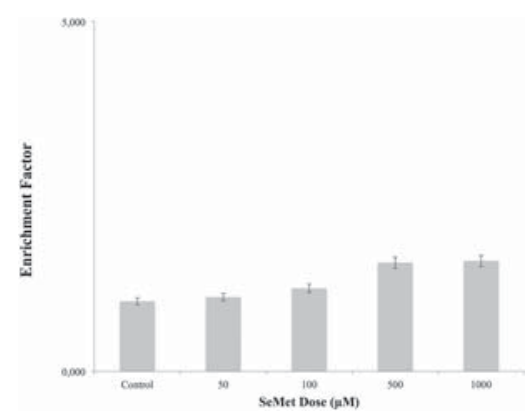

A (c)

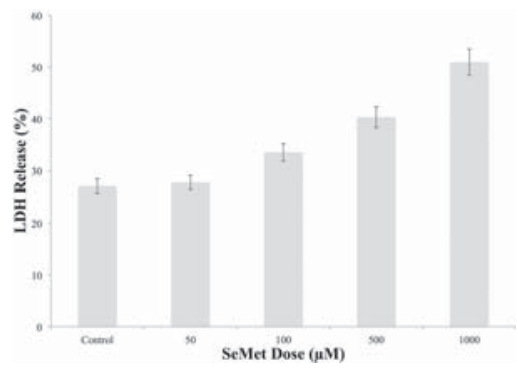

B (c)

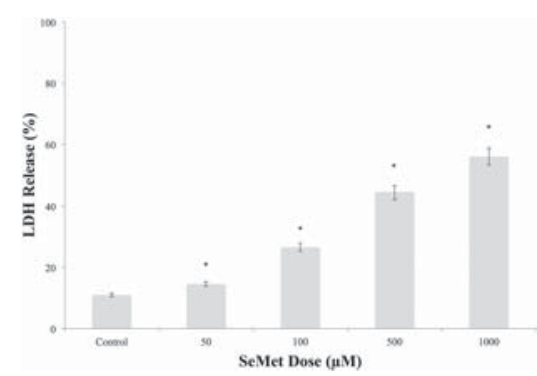

$\mathrm{C}(\mathrm{c})$

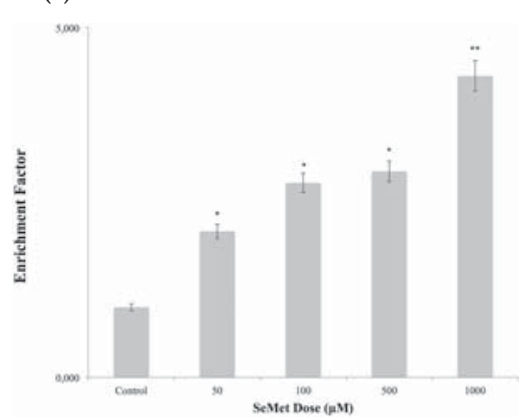

$\mathrm{D}(\mathrm{c})$

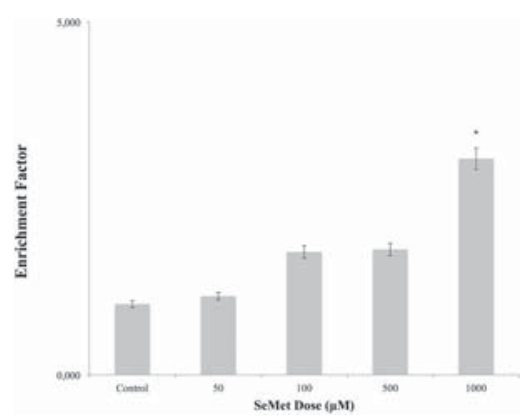

(A) GMS-10 and (B) DBTRG-05MG cells were treated with increasing concentrations of SeMet, and cell death was assayed at different time points: (a) $24 \mathrm{~h}$, (b) $48 \mathrm{~h}$ and (c) $72 \mathrm{~h}$; quantification of apoptosis in (C) GMS-10 and (D) DBTRG-05MG cell lines induced by SeMet at different time points: (a) $24 \mathrm{~h}$, (b) $48 \mathrm{~h}$ and (c) $72 \mathrm{~h}$; quantifying the average optical density (OD) from dead cells and dividing the result by the average control cells yielded the enrichment factor. Data are presented as mean \pm SD $(n=5)\left({ }^{*} p<0.05,{ }^{*} p<0.01\right.$ compared with control group).

Fig. 2. Seleno-L-methionine (SeMet) triggers apoptotic cell death in a dose-dependent manner. 
A (a)

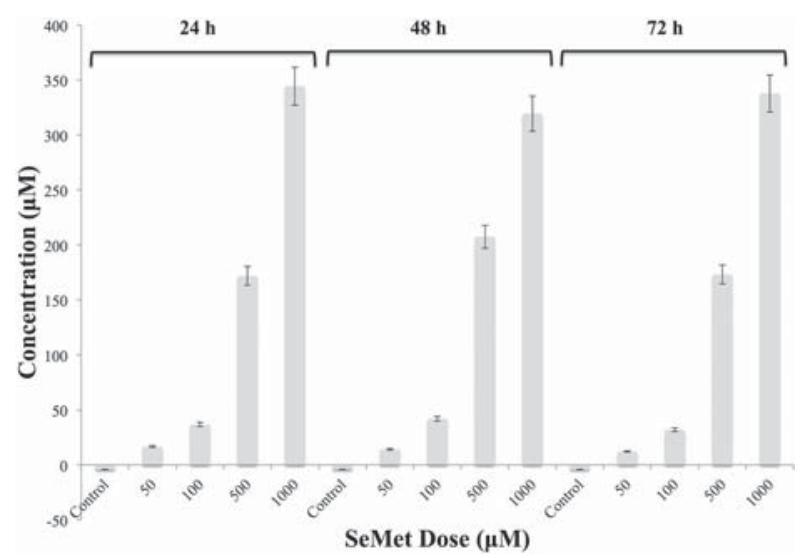

B (a)

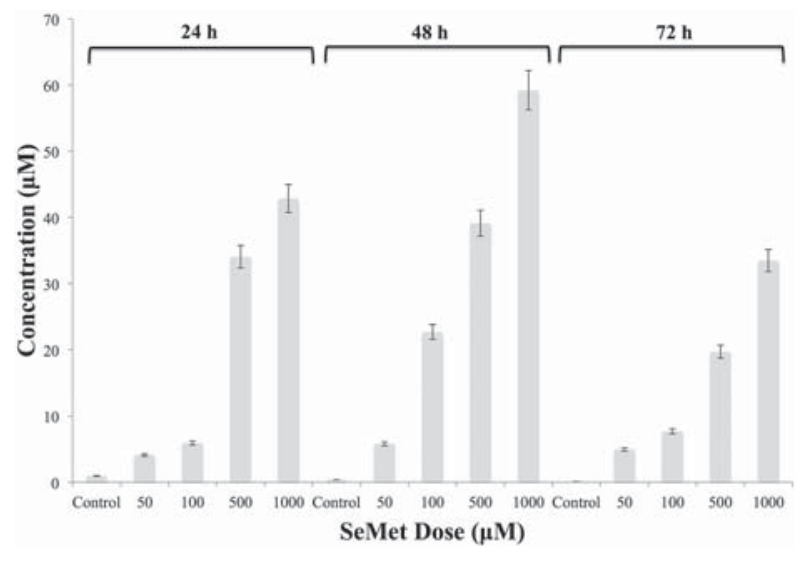

A (b)

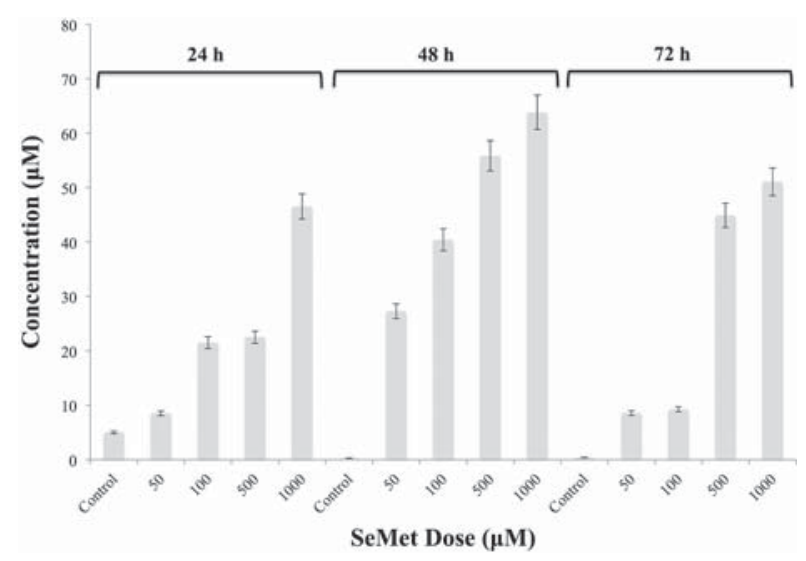

B (b)

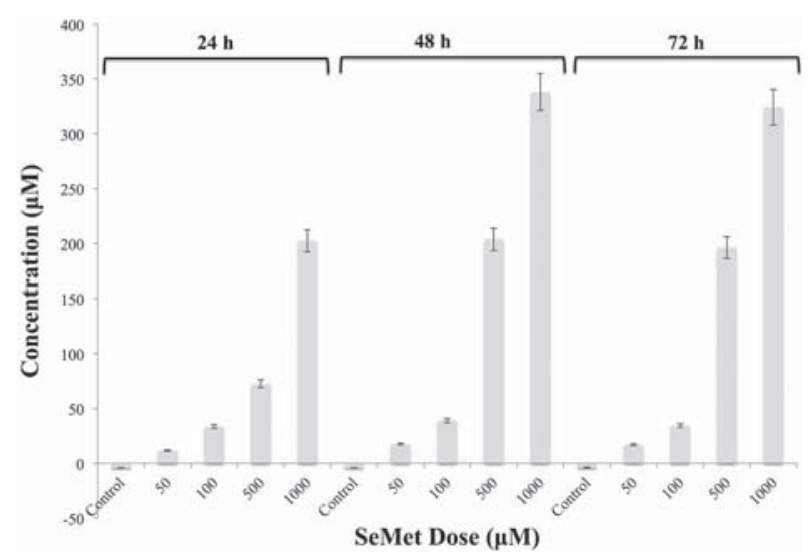

Fig. 3. (A) Seleno-L-methionine (SeMet) levels in GMS-10 (a) and DBTRG-05MG (b) cell lysates at $24 \mathrm{~h}, 48 \mathrm{~b}$ and $72 \mathrm{~b}\left({ }^{* * *} p<0.01,{ }^{*} p<0.05\right)$; (B) SeMet levels in GMS-10 (a) and DBTRG-05MG (b) cell supernatants at $24 \mathrm{~h}$, $48 \mathrm{~h}$ and $72 \mathrm{~h}\left({ }^{* * *} p<0.01,{ }^{*} p<0.05\right)$.

\section{Analysis of intracellular and extracellular selenium levels}

Selenium uptake of the cells was assessed by measuring selenium levels in the supernatants (extracellular) and lysates (intracellular) by GFAAS. At each dose, SeMet uptake was highest at $48 \mathrm{~h}$. However, there was no significant difference compared with the control group.

\section{Ki-67 protein expression}

The SDS-PAGE and Western blotting determined protein levels of $\mathrm{Ki}-67$ following SeMet treatment. $\mathrm{Ki}-67$ band images were shown in the GMS-10 cells at $24 \mathrm{~h}$ (UVP BioImaging System, UK).

\section{Discussion and Conclusions}

The 'magic bullet theory' proposed by Paul Ehrlich a century ago still remains valid in the treatment of cancer. According to Ehrlich, the magic bullet is a compound that targets a single certain oncoprotein in a highly specific fashion and does not damage healthy cells $^{31}$. Today, current research is focused on targeted molecular treatment alternatives. This situation is valid for GBM. The development of drug resistance is a common condition in GBM. The most important problem with drugs is associated with those that cannot pass the blood-brain barrier ${ }^{32}$. Selenium can cross the blood-brain barrier and selenoprotein $\mathrm{P}$ is expressed in the brain ${ }^{33}$. The chemical form of selenium 


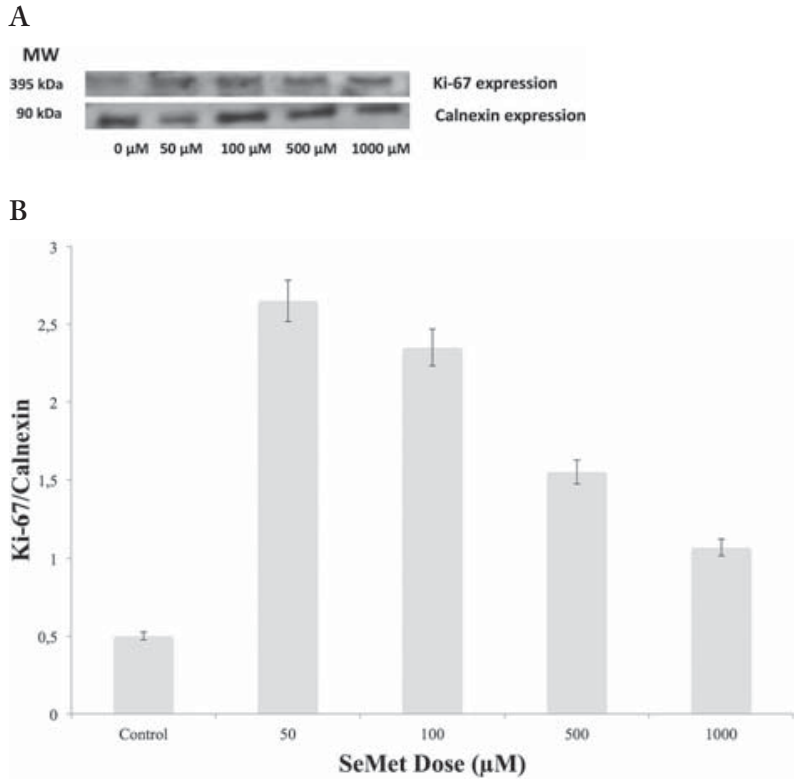

Fig. 4. (A) Protein bands of Ki-67 determined by Western blot performed on the GMS-10 cell line, as well as those of calnexin. From left to right: bands show untreated control and samples treated with 50-1000 $\mu \mathrm{M}$ SeMet for $24 \mathrm{~h}$; (B) densitometric analysis of the bands normalized with calnexin.

is significant. Inorganic forms of selenium are more toxic than organic forms of selenium. Selenomethionine is an organic form of selenium possessing anticancer properties. First data came from the Nutritional Prevention of Cancer (NPC) study, which indicated that selenium compounds have chemopreventive properties, but then the SELECT study has reported debate on the issue ${ }^{34}$.

The GMS-10 glioblastoma cells used are cancerous brain cells derived from a GBM patient ${ }^{23}$. DBTRG$05 \mathrm{MG}$ cells were obtained from a GBM patient having undergone surgery after chemotherapy and radiotherapy ${ }^{24}$. GMS-10 cells are null for p53 gene, but DBTRG-05MG cells have not lost their heterozygos- ity for the $\mathrm{p} 53^{23,24}$. After $24-\mathrm{h}$ SeMet treatment, two tumor cells were affected differently. The $50 \mu \mathrm{M}$ and $100 \mu \mathrm{M}$ SeMet treatment of GMS-10 cells for $24 \mathrm{~h}$ unexpectedly exerted proliferative activity, but under these conditions DBTRG-05MG cells were not affected. Interesting enough, in a way contrary to the nature of antioxidants, SeMet did not fight the cancer cells at $50-\mu \mathrm{M}$ and $100-\mu \mathrm{M}$ doses. Similarly, Sayin et al. demonstrated that antioxidants accelerated lung cancer progression in mice ${ }^{35}$. In this study, this difference may have resulted from differences in p53 status.

In this investigation, SeMet treatment decreased cell proliferation and showed cytotoxicity in a doseand incubation period-dependent manner in both cell lines (except for $50 \mu \mathrm{M}$ and $100 \mu \mathrm{M}$ SeMet treatment of GMS-10 cells for $24 \mathrm{~h}$ ). Furthermore, these parameters correlated to a large extent with the level of SeMet having entered the cells.

Previous studies have shown that SeMet affected different cell types at different concentrations and incubation times. Redman et al..$^{36}$ found that $\mathrm{IC}_{50}$ levels of $45 \mu \mathrm{M}$ SeMet for MCF-7/S cells, $50 \mu \mathrm{M}$ SeMet for UACC-375 cells, $130 \mu \mathrm{M}$ SeMet for HT-29 cells, $40 \mu \mathrm{M}$ SeMet for DU-145 cells, $65 \mu \mathrm{M}$ SeMet for A5 49 cells and $1 \mathrm{mM}$ SeMet for fibroblast cells inhibited $50 \%$ of the growth. Suzuki et al. ${ }^{37}$ applied SeMet in the range of $10-1000 \mu \mathrm{M}$ to HSC-3, HSC-4, A549 and MCF-7. In the present study, the $\mathrm{IC}_{50}$ values for SeMet were $500 \pm 200 \mu \mathrm{M}$ for GMS-10 and $500 \pm 100$ $\mu \mathrm{M}$ for DBTRG-05MG. Given that GBM is the most aggressive and resistant primary brain tumor, such higher values are expected for GBM. The amount of selenium daily intake for normal people is 55 to 70 $\mathrm{mg} /$ day. The body can tolerate maximum selenium level of $400 \mathrm{mg} / \mathrm{day}^{38}$. The doses used in this study were slightly higher than the recommended daily allowance, but they were still within the tolerable range.

In reviewing the literature, $\mathrm{Zhu}$ et al. ${ }^{21}$ showed that selenite $(0.01-100 \mu \mathrm{M})$ inhibited cell growth on $\mathrm{C} 6$

Table 1. Pearson's correlation analysis of cell death and cell proliferation after seleno-Lmethionine (SeMet) treatment

\begin{tabular}{|l|c|c|c|c|c|c|}
\hline \multirow{2}{*}{} & \multicolumn{2}{|c|}{$24 \mathrm{~h}$} & \multicolumn{2}{c|}{$48 \mathrm{~h}$} & \multicolumn{2}{c|}{$72 \mathrm{~h}$} \\
\cline { 2 - 7 } & $\mathrm{r}$ & $\mathrm{p}$ & $\mathrm{r}$ & $\mathrm{p}$ & $\mathrm{r}$ & $\mathrm{p}$ \\
\hline GMS-10 & -0.505 & $<0.05$ & -0.821 & $<0.01$ & -0.934 & $<0.01$ \\
\hline DBTRG-05MG & -0.809 & $<0.01$ & -0.845 & $<0.01$ & -0.941 & $<0.01$ \\
\hline
\end{tabular}

GMS-10 and DBTRG-05MG = human glioblastoma multiforme cell lines 
rat and A172 human glioblastoma cells for 24, 48 and $72 \mathrm{~h}$. They also determined that A172 cells responded more sensitively than $\mathrm{C} 6$ cells. In another study, Zhu et al. ${ }^{20}$ showed that selenite induced apoptosis on A172 and T98 human glioblastoma cells. In this study, we found that after 24-h and 48-h SeMet treatment, DBTRG-05MG cell death increased significantly at high doses $(500$ and $1000 \mu \mathrm{M})$, but GMS-10 cells were not killed by SeMet after $24 \mathrm{~h}$, whereas they were killed at the $500 \mu \mathrm{M}$ dose significantly after 48 -h incubation. After 72-h SeMet incubation, DBTRG-05MG cell death increased at 100, 500 and $1000 \mu \mathrm{M}$ doses significantly, and GMS-10 cells were killed by SeMet on the same doses but not significantly. As a result of the WST-1 and LDH assays, negative correlation was found between the proliferation and cytotoxicity findings and these parameters correlated to a large extent with the level of SeMet entering the cells. The highest SeMet level in both cell lines was measured after 48-h treatment. These findings correspond to the results of proliferation assays and suggest that SeMet cytotoxicity appears to be explained in part by the induction of apoptosis. Interestingly, we observed a significant increase in apoptosis in both cell lines. This condition may be related to the cell p53 status and the development of SeMet resistance in GMS-10 cells. Seo et al..$^{39}$ showed that SeMet could activate the $\mathrm{p} 53$ protein by a redox mechanism and SeMet differentially affected cells wild type or null for $\mathrm{p} 53$ genes. In the view of such information, our data must be supported by new experiments such as siRNA transfection and apoptosis assays.

$\mathrm{Ki}-67$ is a well-known proliferation marker, such as cyclin E, cyclin D and proliferating cell nuclear antigen (PCNA) ${ }^{36}$. Previous studies evaluated Ki-67 protein levels by immunohistochemistry, ELISA or Western blotting ${ }^{40-42}$. Jin et al. ${ }^{43}$ showed that $\mathrm{Ki}-67$ was associated with cell growth and regulating proliferation in GBM. In the present study, $\mathrm{Ki}-67$ band images were determined on GMS-10 cells at $24 \mathrm{~h}$ and also at $48 \mathrm{~h}$, but at $48 \mathrm{~h}$ and $72 \mathrm{~h}$ reproducible band images were not achieved. These findings suggest that $\mathrm{Ki}-67$ is one of the examples of the proliferation signature in GBM, but further studies are needed to evaluate Ki-67 protein levels with other components of cellular proliferation signaling.

This is the first study to examine SeMet effects on cell growth and death in GMS-10 and DBTRG-
05MG cells. Our findings indicate that SeMet induces cell death at high doses, but increases cell proliferation at low doses. Altogether, SeMet appears to be a promising agent for GBM therapy, and the therapeutic potential of SeMet, alone or in combination with conventional treatment agents, warrants additional studies.

\section{Acknowledgments}

We thank Dr. M. Bulbul for kindly helping with the use of GFAAS. This study was carried out in Dokuz Eylül University Medical Faculty Learning Resources Center Research Laboratory (R-LAB). The research project was supported by Dokuz Eylül University Research Funding Department (Project No: 2011.KB: SAG.024).

\section{References}

1. Roman M, Jitaru P, Barbante C. Selenium biochemistry and its role for human health. Metallomics. 2014 Jan 6(1):25-54. DOI: $10.1039 / \mathrm{c} 3 \mathrm{mt} 00185 \mathrm{~g}$

2. Rayman MP. Selenium in cancer prevention: a review of the evidence and mechanism of action. Proc Nutr Soc. 2005;64: 527-42.

3. Jackson MI, Combs GF. Selenium and anticarcinogenesis: underlying mechanisms. Curr Opin Clin Nutr Metab Care. 2008;11:718-26. DOI: 10.1097/MCO.0b013e3283139674

4. Mckenzie RC, Arthur JR, Beckett GJ. Selenium and the regulation of cell signaling, growth, and survival: molecular and mechanistic aspects. Antioxid Redox Sign. 2002;4(2):339-51. DOI: $10.1089 / 152308602753666398$

5. Zhong W, Oberley TD. Redox-mediated effects of selenium on apoptosis and cell cycle in the $\mathrm{LNCaP}$ human prostate cancer cell line. Cancer Res. 2001;61:7071-8.

6. Jiang C, Wang Z, Ganther H, Lü J. Distinct effects of methylseleninic acid versus selenite on apoptosis, cell cycle, and protein kinase pathways in DU145 human prostate cancer cells. Mol Cancer Ther. 2002;1:1059-66.

7. Hawkes WC, Alkan Z. Delayed cell cycle progression from SEPW1 depletion is p53- and p21-dependent in MCF-7 breast cancer cells. Biochem Biophys Res Commun. 2012; 413:36-40. DOI: $10.1002 /$ jcb. 23328

8. Mut M, Schiff D. Unmet needs in the treatment of glioblastoma. Anticancer Ther. 2009;9(5): 545-51. DOI: 10.1586/ era.09.24

9. Groot J, Milano V. Improving the prognosis for patients with glioblastoma: the rationale for targeting Src. J Neurooncol. 2009;95:151-63. DOI: 10.1007/s110060-009-9916-2

10. Midi A, Belirgen M, Sav A, Bozkurt S, Midi I, K1lıc T. Giant cell glioblastoma; long-term survival, and correlation with usual glioblastoma. J Neurosurg Sci. 2008;25(4):272-82. 
11. Oktar N, Özgiray E, Akalın T. Long term survivors of glioblastoma. J Neurosurg Sci. 2009;26(4):376-82.

12. Wen PY, Brandes AA. Treatment of recurrent high-grade gliomas. Curr Opin Neurol. 2009;22(6):657-64. DOI: 10.1097/ WCO.0b013e32833229e3

13. Cohen MH, Shen YL, Keegan P, Pazdur R. FDA drug approval summary: Bevacizumab (avastin) as treatment of recurrent glioblastoma multiforme. Oncologist. 2009;14(11): 1131-8. DOI: 10.1634/theoncologist.2009-0121

14. Van Meir EG, Hadjipanayis CG, Norden AD, Shu HK, Wen PY, Olson JJ. Exciting new advances in neuro-oncology: the avenue to a cure for malignant glioma. CA Cancer J Clin. 2010;60(3):166-93. DOI: 10.3322/caac.20069

15. Nyman DW, Stratton MS, Kopplin MJ, Dalkin BL, Nagle RB, Jay Gandolfi A. Selenium and selenomethionine levels in prostate cancer patients. Cancer Detect Prev. 2004;28:8-16. DOI: 10.1016/J.CDP.2003.11.002

16. Selenius M, Fernandes AP, Brodin O, Björnstedt M, Rundlöf AK. Treatment of lung cancer cells with cytotoxic levels of sodium selenite: effects on the thioredoxin system. Biochem Pharm. 2008;75:2092-9. DOI: 10.1016/j.bcp.2008.02.028

17. Zeng H, Briske-Anderson M, Wu M, Moyer MP. Methylselenol, a selenium metabolite, plays common and different roles in cancerous colon HCT116 cell and noncancerous NCM460 colon cell proliferation. Nutr Cancer. 2012;64(1):128-35. DOI: 10.1080/01635581.2012.630555

18. Song H, Hur I, Park H, Nam J, Park GB, Kong KH, et al. Selenium inhibits metastasis of murine melanoma cells through the induction of cell cycle arrest and cell death. Immune Network. 2009;9(6):236-42. DOI: 10.4110/in.2009.9.6.236

19. Sundaram N, Pahwa AK, Ard MD, Lin N, Perkins E, Bowles AP Jr. Selenium causes growth inhibition and apoptosis in human brain tumor cell lines. J Neurooncol. 2000;46:125-33.

20. Zhu Z, Kimura M, Itokawa Y, Aoki T, Takahashi JA, Nakatsu $\mathrm{S}$, et al. Apoptosis induced by selenium in human glioma cell lines. Biol Trace Elem Res. 1996;54:123-34.

21. Zhu Z, Kimura M, Itokawa Y, Nakatsu S, Oda Y, Kikuchi H. Effect of selenium on malignant tumor cells of brain. Biol Trace Elem Res. 1995;49:1-7.

22. Rooprai HK, Kyriazis I, Nuttall RK, Edwards DR, Zicha D, Aubyn D, et al. Inhibition of invasion and induction of apoptosis by selenium in human malignant brain tumour cells in vitro. Int J Oncol. 2007;30:1263-71. DOI: 10.3892/ijo.30.5.1263

23. Deutche Sammlung von Microorganismen und Zellkulturen GmbH [Internet] 14.11.2013 15.32 pm. Available from: http: //www.dsmz.de/catalogues/details/culture/ACC-405.html?tx_ dsmzresources_pi5[returnPid]=192.

24. Kruse AC, Mitchel DH, Kleinschmidt-deMasters BK, Franklin WA, Morse HG, Spector EB, et al. Characterization of a continuous human glioma cell line DBTRG-05MG: growth kinetics, karyotype, receptor expression, and tumor suppressor gene analyses. In Vitro Cell Dev Biol. 1992;28:609-14.

25. Berridge MV, Herst PM, Tan AS. Tetrazolium dyes as tools in cell biology: new insights into their cellular reduction. Bio- technol Annu Rev. 2005;11:127-52. DOI: 10.1016/S13872656(05)11004-7

26. Srivastava R. Comparison of in vivo acute lethal potency and in vitro cytotoxicity of 48 chemicals. Cell Biol Toxicol. 1992;8: 157-70.

27. Jacobson BE, Lockitch G. Direct determination of selenium in serum by graphite-furnace atomic absorption spectrometry with deuterium background correction and reduced palladium modifier: age-specific reference ranges. Clin Chem. 1988;34 (4):709-14.

28. Burgin C, Gray TA, Morris BW. Serum selenium measured by Zeeman electrothermal atomic absorption spectrophotometry. Met Ions Biol Med. 1998;5:18-22.

29. Ferrer E, Alegria A, Barbera R, Fare R, Lagarda MJ. Whole blood selenium determination: optimization of an ET-AAS method. Met Ions Biol Med. 1998;5:23-7.

30. Burnette WM. 'Western blotting': electrophoretic transfer of proteins from sodium dodecyl sulfate-polyacrylamide gels to unmodified nitrocellulose and radiographic detection with antibody and radioiodinated protein A. Anal Biochem. 1981; 112:195-203.

31. Pellegatta S, Cuppini L, Finocchiaro G. Brain cancer immunoediting: novel examples provided by immunotherapy of malignant gliomas. Expert Rev Anticancer Ther. 2011;11(11): 1759-74. DOI: 10.1586/era.11.102

32. Sarafian V, Koev I, Staykov D. Mechanisms of cell resistance in glioblastoma multiforme. J IMAB. 2009;1:6-8.

33. Sunde AR, Raines AM. Selenium regulation of the selenoprotein and nonselenoprotein transcriptomes in rodents. Adv. Nutr. 2011;2:138-50. DOI: 10.3945/an.110.000240

34. Lippman SM, Goodman PJ, Klein EA, Parnes HL, Thompson IM Jr, Kristal AR, et al. Designing the Selenium and vitamin E Cancer prevention Trial (SELECT). J NCI. 2005;97(2): 94-102. DOI: $10.1093 /$ jnci/dji009

35. Sayin V, Ibrahim MX, Larsson E, Nilsson JA, Lindahl P, Bergo MO. Antioxidants accelerate lung cancer progression in mice. Sci Transl Med.2014;6(221):221ra15. DOI: 10.1126/scitranslmed.3007653

36. Redman C, Scott JA, Baines AT, Basye JL, Clark LC, Calley C, et al. Inhibitory effect of selenomethionine on the growth of three selected human tumor cell lines. Cancer Lett. 1998; 125:103-10. DOI: http://dx.doi.org/10.1016/S0304-3835(97) 00497-7

37. Suzuki M, Endo M, Shinohara F, Echigo S, Rikilishi H. Differential apoptotic response of human cancer cells to organoselenium compounds. Cancer Chemother Pharmacol. 2010;66: 475-84. DOI: 10.1007/s00280-009-1183-6

38. Wang H, Zhang J, Yu H. Elemental selenium at nano size possesses lower toxicity without compromising the fundamental effect on selenoenzymes: comparison with selenomethionine in mice. Free Radic Biol Med. 2007;42:1524-33. DOI: 10.1016/j. freeradbiomed.2007.02.013

39. Seo YR, Kelley MR, Smith ML. Selenomethionine regulation of p53 by a ref1-dependent redox mechanism. PNAS. 2002; 99(2):14548-53. DOI: 10.1073/pnas.212319799 
40. Whitfield ML, George LK, Grant GD, Perou CM. Common markers of proliferation. Nature Rev. 2006;6:99-106. DOI: $10.1038 /$ nrc1802

41. Brown DC, Gatter KC. Ki67 protein: the immaculate deception? Histopathology. 2002;40:2-11. DOI: 10.1046/j.1365$-2559.2002 .01343 . x$
42. Scholzen T, Gerdes J. The Ki-67 protein: from the known and the unknown. J Cell Physiol. 2000;182:311-22. DOI: 10.1002/ (SICI)1097-4652(200003)182:3<311::AID-JCP1>3.0.CO;2-9

43. Jin Q, Zhang W, Qiu XG, Yan W, You G, Liu YW, et al. Gene expression profiling reveals $\mathrm{Ki}-67$ associated proliferation signature in human glioblastoma. Chin Med J. 2011;124(17):2584-8.

Sažetak

\section{IN VITRO UČINCI SELENA NA STANIČNE LINIJE HUMANOG GLIOBLASTOMA MULTIFORME: PRELIMINARNO ISTRAŽIVANJE}

\section{Harmanci, Z. Erbayraktar, O. Sayin i G. Akdogan Guner}

Glioblastom multiforme (GBM) uzrokuju glijalne stanice podrijetlom iz središnjega živčanog sustava i to je najčešći (50\%-60\%) oblik primarnog tumora mozga. Cilj ovoga istraživanja bio je ispitati in vitro učinke selena na stanice humanog GBM. Rabili smo stanične linije GMS-10 i DBTRG-05MG humanog GBM kao model za ispitivanje ulaska selena u stanicu, stanične proliferacije, citotoksičnosti, fragmentacije DNA i izraženosti proteina Ki-67 u skupini tretiranoj selenometioninom i skupini bez takve obrade. Seleno-L-metionin (SeMet) kao organski izvor selena utjecao je na staničnu proliferaciju i citotoksičnost, što je procijenjeno pomoću testova WST-1 odnosno laktat dehidrogenaze (LDH). Apoptoza je procijenjena fragmentacijom DNA testom ELISA. Izražajnost proteina Ki-67 utvrđena je Western blotingom, dok su mjerenja selena provedena u supernatantima, a lizati primjenom GFAAS. Ovo je prvo istraživanje u kojem su se ispitivali učinci SeMet na staničnu proliferaciju i smrt u stanicama GMS-10 i DBTRG-05MG. Obje stanične linije GBM pokazale su o dozi i vremenu ovisan odgovor na SeMet. Test WST-1 pokazao je da je tretman niskom dozom SeMet (50 i $100 \mu \mathrm{M}$ ) povećao proliferaciju stanica. Rezultati analize unutarstaničnih razina SeMet pomoću AAS bili su sukladni rezultatima testova stanične životnosti i citotoksičnosti. Tretman pomoću SeMet kroz $72 \mathrm{~h}$ uzrokovao je povećanu fragmentaciju DNA u objema staničnim linijama. U zaključku, naši rezultati ukazuju na to da SeMet u visokim dozama izaziva staničnu smrt, dok u niskim dozama povećava staničnu proliferaciju. U svjetlu podataka dobivenih u ovom istraživanju smatramo da bi bilo opravdano daljnja istraživanja usredotočiti na moguću primjenu SeMet kod različitih tipova GBM i u kombinaciji s mogućim sinergističnim spojevima.

Ključne riječi: Glioblastom - terapija; Antikancerogeni lijekovi; Ljudi; Selen; Selenometionin; Stanična proliferacija - učinci lijekova; Stanična smrt-učinci lijekova; antigen Ki-67 